\title{
PAPER RECYCLING EFFICIENCY IN FUNCTION OF THE TYPEFACE
}

\author{
BOLANCA MiRKOVIC, I. \& MOZINA, K.
}

Abstract: Eco-design has become very important in last few years. According to the environmental suggestions not to waste materials, energy etc., and use of recycle materials we were study paper recycling process in relation to used printed typefaces, their sizes and used different leading. For prints conventional and model offset inks with greater environmental benefits were used for printing. Characteristics of the recycled fibers followed by image analysis and some spectrophotometric methods are discussed. The results of these studies except for the scientific contribution should serve as a reference in design, especially for environmentally friendly graphic products.

Key words: recycling, typeface, type size, image analysis, reflectance
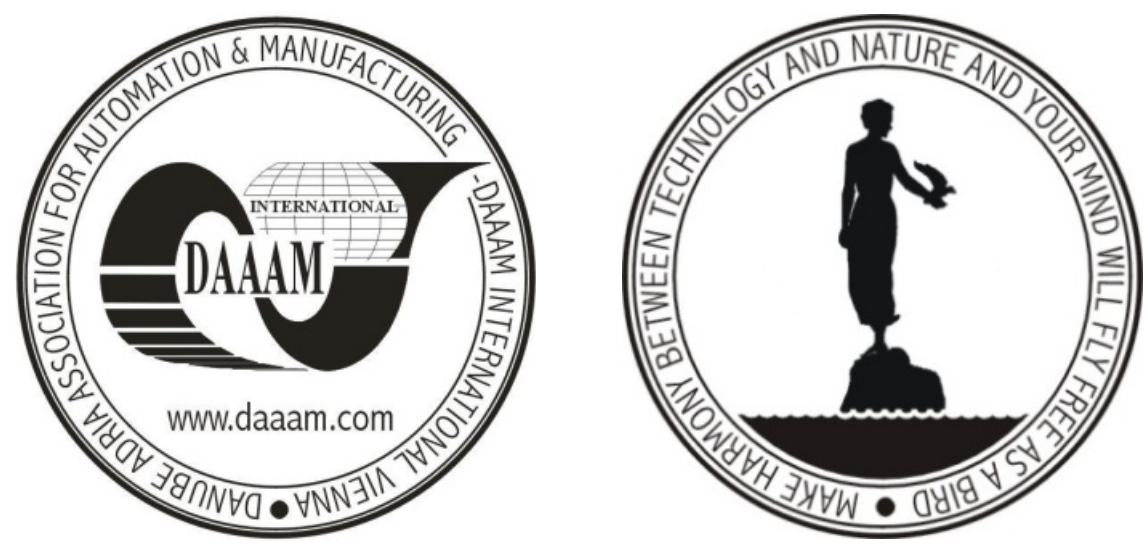

Authors' data: Assist. Prof. Dr. Sc. Bolanca Mirkovic, I[vana]*; Assist. Prof. Dr. Sc. Mozina, K[lementina]**, *University of Zagreb, Faculty of Graphic Arts, Getaldiceva 2, 10000, Zagreb, Croatia, ** University of Ljubljana, Faculty of Natural Sciences and Engineering, Snezniska 5, 1000, Ljubljana, Slovenia, ibolanca@grf.hr, klementina.mozina@ntf.uni-lj.si

This Publication has to be referred as: Bolanca Mirkovic, I[vana] \& Mozina, K[lementina] (2009). Paper Recycling Efficiency in Function of the Typeface, Chapter 58 in DAAAM International Scientific Book 2009, pp. 599-612, B. Katalinic (Ed.), Published by DAAAM International, ISBN 978-3-901509-69-8, ISSN 17269687, Vienna, Austria

DOI: $10.2507 /$ daaam.scibook.2009.58 